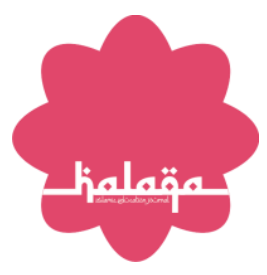

\title{
Management of New Student Admissions for SMA Muhammadiyah 2 Sidoarjo in the Covid-19 Pandemic Era
}

\section{Manajemen Penerimaan Peserta Didik Baru SMA Muhammadiyah 2 Sidoarjo di Era Pandemi Covid-19}

\author{
Muhammad Mauludy Falaakhy ${ }^{1 *}$, Biyanto ${ }^{2}$, Eni Fariyatul Fahyuni ${ }^{3}$ \\ ${ }^{1,3}$ Magister Manajemen Pendidikan Islam Universitas Muhammadiyah SIdoarjo, 2fUniversitas Islam Negeri Sunan \\ Ampel Surabaya, Indonesia
}

At the end of May 2020, Nadiem Anwar Makarim, the Minister of Education issued a circular letter Number 4 of 2020, regarding the implementation of education policies during the Coronavirus Disease (Covid-19) emergency. In its application, many PPDB management activities must be able to adapt to the rules of the Indonesian government, therefore school management makes steps \& policies related to PPDB related to planning, implementation, control so that they can get success. PPDB activities are an implementation process that is indispensable as process stability in the education sector. The Management function in its stages includes Planning, organizing, implementing, and supervising. The idea of management was put forward by Joseph Juran. There is a need for good quality planning and is known as Strategic Quality Management, namely the quality improvement process. Juran's concept is called the Juran Trilogy (1989) which states that quality management consists of three main parts, namely: (a) quality planning, (b) quality control, and (c) quality improvement. The purpose of this study was to obtain an overview of the management of new student admissions at the high school level during the Covid-19 pandemic. This research is a type of qualitative descriptive research model, with data collection techniques namely observation, interviews, documentation, and data triangulation. Based on the results of research conducted in SMA Muhammadiyah 2 Sidoarjo (SMAMDA), the researchers got the results of research that the implementation of acceptance of new students at SMAMDA went through several stages of selection that must be followed by prospective SMAMDA students, namely: Computer Based Test, Determination of Academic Values, Interviews and Urine test for all registration lines. Furthermore, the UPT PPDB will announce the results of the exam on the PPDB website for SMAMDA.

Keywords: New Student Admission, Covid-19 Pandemic, Management 
Pada akhir bulan Mei 2020 Nadiem Anwar Makarim Menteri Pendidikan mengeluarkan surat edaran (SE) Nomor 4 Tahun 2020, tentang pelaksanaan kebijakan pendidikan pada saat darurat Coronavirus Disease (Covid-19). Dalam penerapannya, banyak sekali kegiatan manajemen PPDB yang harus bisa beradaptasi dengan aturan pemerintah $\mathrm{RI}$, oleh sebab itu manajemen sekolah membuat langkah \& kebijakan yang berkaitan dengan PPDB terkait perencanaan, pelaksanaan, pengendalian sehingga bisa mendapatkan keberhasilan. Kegiatan PPDB merupakan proses pelaksanaan yang sangat diperlukan sebagai stabilitas proses di bidang pendidikan. Fungsi Manajemen dalam tahapan-tahapannya meliputi: Perencanaan, pengorganisasian, implementasi dan pengawasan. Gagasan manajemen dikemukakan Joseph Juran. Perlu adanya perencanaan kualitas yang baik dan dikenal sebagai Strategic Quality Management yaitu proses perbaikan kualitas. Konsep Juran ini disebut Trilogi Juran (1989) menyebutkan bahwa manajemen mutu terdiri dari tiga bagian pokok, yaitu: (a) perencanaan mutu, (b) pengendalian mutu, dan (c) peningkatan mutu. Tujuan penelitian ini adalah untuk memperoleh gambaran manajemen penerimaan peserta didik baru di jenjang SMA pada masa Pandemi Covid-19. Penelitian ini merupakan jenis penelitian model deskriptif kualitatif, dengan teknik pengumpulan data yaitu observasi, wawancara, dokumentasi dan triangulasi data. Berdasarkan hasil penelitian yang dilakukan di lingkungan SMA Muhammadiyah 2 Sidoarjo maka peneliti mendapatkan hasil penelitian bahwa pelaksanaan penerimaan peserta didik baru di SMA Muhammadiyah 2 Sidoarjo melalui beberapa tahapan seleksi yang wajib diikuti oleh calon siswa SMAMDA, yaitu: Computer Based Test, penentuan Nilai Akademik, Wawancara dan Tes urine untuk semua jalur pendaftaran. Selanjutnya, pihak UPT PPDB akan mengumumkan hasil ujian di website PPDB SMA Muhammadiyah 2 Sidoarjo.

Kata Kunci: Penerimaan Peserta Didik Baru, Pandemi Covid-19, Manajemen 


\section{PENDAHUUAN}

Indonesia pada saat ini dihadapkan dengan berbagai masalah internal dan eksternal yang disebabkan oleh berbagai perubahan seperti perubahan sosial, perubahan teknologi dan perubahan budaya, terutama mempengaruhi kemajuan dan perkembangan pendidikan. Sebagai negara yang masih tergolong negara berkembang, Indonesia sedang mencari cara dan upaya untuk menjadi negara yang maju khususnya di bidang pendidikan. Sistem pendidikan di Indonesia mengacu pada sistem pendidikan nasional, yaitu sistem pendidikan yang akan membawa kemajuan dan pembangunan bagi negara dan menjawab tantangan yang terus berubah.Negara Republik Indonesia No. Tentang SISDIKNAS No. 20 tahun 2003 adalah sebagai berikut: "Terwujudnya sistem pendidikan sebagai pranata sosial yang kuat dan berwibawa untuk memberdayakan semua warga Negara Indonesia berkembang menjadi manusia yang berkualitas sehingga mampu dan proaktif menjawab tantangan zaman yang selalu berubah." Tugas yang dilakukan oleh SISDIKNAS adalah: "Mengupayakan perluasan dan pemerataan kesempatan memperoleh pendidikan yang bermutu bagi seluruh rakyat." [UU RI SISDIKNAS No. 20 Tahun 2003] Dalam penerapan SISDIKNAS pendidikan di Indonesia Menciptakan suasana belajar dan proses pembelajaran yang memungkinkan peserta didik secara aktif mengembangkan potensi dirinya untuk memiliki kekuatan spiritual keagamaan, pengendalian diri, kepribadian, kecerdasan, akhlak mulia dan keterampilan yang dibutuhkan oleh dirinya, masyarakat, negara dan negara.

Muhammadiyah bisa dibilang pelopor Pembaharuan Pendidikan Islam di Indonesia yang sejalan dengan visi dan misi SISDIKNAS. Perjuangan K.H Ahmad Dahlan yang merupakan pendiri Muhammadiyah dapat dirasakan manfaatnya hingga saat ini. Kelahiran Muhammadiyah yang telah melewati 1 abad, diawali oleh dakwahnya dalam dunia pendidikan. Hal ini kemudian menjadi trade mark nya hingga sekarang. Tugas terpenting adalah misi meningkatkan kemajuan masyarakat dan kemajuan bangsa. Muhammadiyah merupakan organisasi swasta yang memiliki amal usaha dalam bentuk sekolah atau institusi pendidikan yang tersebar di seluruh Indonesia. Tujuan Pendidikan Muhammadiyah adalah mewujudkan dan menumbuhkan manusia religius, orang Islam yang menguasai "ilmu-ilmu agama" maupun "ilmu-ilmu umum" sekaligus di mana secara individual seluruh potensi/fitrahnya tumbuh optimal sehingga bisa menjadi pribadi yang cerdas (inteligen). Ali (2016) Membentuk generasi muslim, berakhlaq mulia, cerdas, percaya diri, cakap, dan berguna untuk masayarakat umum. Menurut data terbaru yang diperoleh penulis dari profil Muhammadiyah jumlah amal usaha di bidang pendidikan Muhammadiyah adalah 5.797 , jumlah yang cukup besar untuk sebuah lembaga pendidikan yang dinaungi dalam satu payung organisasi dengan data sebagai berikut; $1.132 \mathrm{SD}$ (Sekolah Dasar); 1.769 MI (Madrasah Ibtidaiyah); 1.184 SMP (Sekolah lanjutan /Sekolah Menengah Pertama); 534 MT (Madrasah Tsanawiyah); 511 SMA (Sekolah Menengah Atas); 263 SMK (Sekolah Menengah Kejuruan); 172 MA (Madrasah Aliyah); 67 PONPES (Pondok Pesantren); 55 Akademi; 4 Politeknik; 70 ST (Sekolah Tinggi) dan 36
Universitas yang menyebar di seluruh Indonesia. Ayu (2007)

SMAMDA Sidoarjo merupakan lembaga amal usaha Muhammadiyah yang berkecimpung di bidang pendidikan. Oleh sebab itu lembaga ini sangat berperan dan berfungsi dalam mencerdaskan kehidupan bangsa serta memiliki posisi strategis di dalamya. SMAMDA merupakan lembaga yang mengedepankan nilai-nilai Islam dalam proses penyelenggaraan pendidikan sebagai dasar pembinaan karakter siswa. SMAMDA Sidoarjo telah melalui perjalanan yang cukup panjang, didirikan dengan 6 pendaftar pada awal tahun ajaran tahun 1976, Hingga usianya yang ke-40 tahun, SMAMDA Sidoarjo telah berkembang dan melakukan pembenahan develop and reform di banyak bidang, mulai dari Infrastruktur, pembelajaran dan kurikulum pendidikan. Selain itu proses ini juga meliputi sumber daya manusia maupun pengembangan kultural dan menjadi karakter sekolah. Terdapat beberapa usaha praktis dilaksanakan dengan tujuan agar mewujudkan SMAMDA Sidoarjo menjadi the real school. Artinya sekolah ini berkegiatan dengan menegakkan budaya keilmuan dan semangat keislaman. Dua dasar kegiatan ini diharapkan akan membawa warga sekolah menuju manusia yang berkualitas yaitu beriman dan bertakwa kepada Allah SWT.

Selain itu, diharapkan terbentuk individu dengan penguasaan ilmu pengetahuan dan teknologi, mempunyai kecakapan hidup (life skill), memiliki gaya moral yang baik, santun, dan bertakwa. Dalam proses pendidikan dan pembelajaran yang diselenggarakan, SMAMDA Sidoarjo mengembangkan model pendidikan holistic, yaitu model pendidikan dan pembelajaran yang mengembangkan keseluruhan kecerdasan, meliputi kecerdasan spiritual, kecerdasan emosional, kecerdasan ketangguhan, dan kecerdasan intelektual, didukung oleh pendidik dan tenaga kependidikan yang berkualitas serta profesional dibidangnya, infrastruktur yang representatif, dan lingkungan sekolah yang kondusif dan menyenangkan. Melalui upaya pengembangan dan pembaharuan (development and reform) di berbagai bidang, SMAMDA Sidoarjo memperoleh predikat RSBI pada tahun 2009-2012, dan memperoleh sertifikasi A sebesar 93 poin pada tahun 2016, kemudian memperoleh ISO dari tahun 2011 hingga 2017 selanjutnya mencapai Sertifikasi 9001: 2008. Dalam perjalanannya lembaga ini di tahun 2017 sampai dengan saat ini memegang sertifikasi ISO 9001:2015 oleh URS Indonesia.

Lembaga ini juga meraih gelar yaitu The Outstanding School of Muhammadiyah yang diberikan Pimpinan Wilayah Muhammadiyah Jawa Timur. Pada tahun 2012 lembaga ini meraih penghargaan dalam In Recognation of High Quality Improvement Commitment Company dari House of Quality pada 1st Indonesia World-Class Quality Conference 2012. Ditahun selanjutnya yaitu tahun 2013 lembaga juga meraih kehormatan pada Education \& Educator Indonesia Award 2013 dengan nominasi As The Best Educator \& Education of The Year. Selanjutnya pada tahun 2015 dan 2016 berturut turut lembaga juga ditunjuk sebagai sekolah Induk Cluster Implementasi K13. Lembaga juga diamanahi pada tiga tahun terakhir pada tahun 2018, 2019 dan 2020 sebagai sekolah rujukan dari Kementerian pendidikan dan kebudayaan Republik Indonesia. Pada akhir bulan Mei 2020 Nadiem Anwar Makarim Menteri Pendidikan mengeluarkan surat 
edaran (SE) Nomor 4 Tahun 2020 Isi tentang pelaksanaan kebijakan pendidikan pada saat darurat Coronavirus Disease (Covid-19). Kementerian Pendidikan Dan Kebudayaan (2020) Dalam surat edaran ini, selain menjelaskan pembatalan ujian nasional, juga mengatur pelaksanaan Penerimaan Mahasiswa Baru (PPDB) 2020. Sidoarjo merupakan kawasan yang dilanda pandemi Covid-19 terbesar di Jawa Timur setelah Kota Surabaya. Hal ini ditunjang dengan kondisi Sidoarjo sebagai kota penyangga kegiatan dan perekonomian wilayah Surabaya.

Menurut hasil riset Verra Sofica dkk (2020), menjelaskan bahwa Penerimaan peserta didik baru secara online menjadi solusi terbaik untuk dapat menerima siswa baru bagi sekolah dimasa pandemi Covid-19 ini. Sehingga, Orang tua dan calon siswa akan mendapatkan informasi tentang penerimaan peserta didik baru dengan mudah cukup mengakses website dari rumah tidak perlu datang ke sekolah sehingga dapat menimbulkan kerumunan yang bisa meningkatkan penyebaran Covid-19. Dan proses pembayaran pendaftaran menjadi lebih mudah dengan melakukan transfer via ATM. Paparan tersebut menjelaskan pentingnya proses PPDB di era pandemi Covid-19 lebih mudah dan fleksibel dilaksanakan dalam sistem online. Maka dari itu, peneliti melakukan penelitian tentang Manajemen PPDB sekolah di era pandemi Covid-19 dengan mengambil lokasi SMA Muhammadiyah 2 Sidoarjo sebagai fokus penggalian data di lapangan.

\section{METODE}

\section{Pendekatan dan Jenis Penelitian}

Penelitian ini merupakan jenis penelitian model deskriptif kualitatif. Data yang akan diperoleh bukan dalam bentuk digital, melainkan berupa catatan lapangan dan hasil wawancara. Penelitian kualitatif mengutamakan adanya pendekatan dengan mengungkap situasi sosial tertentu. Langkah ini dilaksanakan dengan deskripsi sebuah tutur kenyataan secara benar dan dianalisis menjadi kalimat dengan metode teknik pengumpulan data yang berbasis relevansi analisis data dan diperoleh dari situasi alamiah". Ambarwati (2016) Desain penelitian ini dimulai pada tahap pengamatan yang selanjutnya peneliti akan mulai menemukan sebuah permasalahan di lapangan. Permasalahan yang dibahas dalam penelitian ini merupakan proses penerimaan peserta didik baru (PPDB) online pada masa pandemi Covid-19 di SMA Muhammadiyah 2 Sidoarjo. Penelitian ini dilakukan berawal dari musibah Pandemi Covid-19 yang memberikan dampak pada dunia manajemen pendidikan. Sebuah manajemen PPDB online yang baik dilaksanakan dalam upaya upaya preventif terhadap penyelenggaraan PPDB online.

\section{Kehadiran Peneliti}

Kehadiran peneliti dalam peneliti kualitatif menjadi sebuah keharusan. Peneliti melakukan penelitian yang didasarkan pada prioritas penelitian, kemudian mengarahkan peneliti ke lapangan untuk mengumpulkan data melalui wawancara dan studi dokumentasi. selanjutnya, peneliti melakukan klasifikasi terhadap data tersebut. Hasil pengolahan data digunakan sebagai hasil penelitian, dapat ditarik kesimpulan, kemudian dapat dijadikan rekomendasi bagi pihak terkait.. pengarahan, meggerakan dan mengevaluasi kinerja dosen tentunya peneliti angkat dan deskripsikan sesuai kondisi yang sebenarnya.

\section{Teknik Pengumpulan Data}

Data yang dibutuhkan dalam penelitian ini adalah tentang semua informasi pengelolaan dan implementasi PPDB online. Fase manajemen meliputi tiga fase: perencanaan, pelaksanaan, dan evaluasi. Ketiga tahapan inilah yang menjadi fokus penelitian, data yang dibutuhkan peneliti ditambah faktor-faktor pendukung keberhasilan dan penghambat. Penelitian yang dilakukan adalah untuk menyelesaikan suatu permasalahan fenomena. Untuk melaksanakan kegiatan tersebut diperlukan beberapa faktor agar berhasil, salah satunya adalah instrumen. Intstrumen dalam penelitian kualitatif adalah peneliti itu sendiri. "Peneliti dalam penelitian kualitatif merupakan orang yang membuka kunci, menelaah dan mengksplorasi seluruh ruang secara cermat, tertib dan leluasa, dan bahkan ada yang menyebutkannya sebagai key instrument". Komariah \& Satori (2014)

Satori dan Komarian mengemukakan"Peneliti terjun secara langsung ke lapangan untuk mengumpulkan sejumlah informasi yang dibutuhkan dengan terlebih dahulu sudah memiliki beberapa pedoman yang akan dijadikan alat bantu pengumpulan data. Pedoman tersebut digunakan dalam pencarian data di lapangan dengan menggunakan teknik yang tepat". Pengumpulan data menjadi teknik yang penting dalam mengambil sebuah langkah penelitian, karena proses utama dalam penelitian adalah mencari data. Penelitian dengan metode deskriptif kualitatif menggunakan teknik pengumpulan data dengan cara observasi, wawancara mendalam dan dokumentasi.

\section{Teknik Analisis Data}

Menurut Bogdan dan Biklen menyatakan bahwa, "analisis data kualitatif adalah upaya yang dilakukan dengan jalan bekerja dengan data, mengorganisasikan data, memilahmilahnya menjadi satuan yang dapat dikelola, mensintesiskannya, mencari dan mengemukakan pola, menemukan apa yang penting dan apa yang dipelajari, dan memutuskan apa yang dapat diceritakan kepada orang lain" . Miles dan Huberman mengemukakan bahwa "terdapat tiga langkah dalam analisis data, yaitu reduksi data, display data dan verifikasi data": Milles \& Huberman (1992) a) Reduksi Data. Mereduksi data berarti meringkas, memilih konten utama, fokus pada konten penting, menemukan tema dan pola, dan menghilangkan yang tidak perlu. Sehingga hal ini memudahkan peneliti untuk melakukan pengumpulan data lebih lanjut; b) Display Data. Setelah mereduksi data, langkah selanjutnya dalam analisis data adalah menampilkan atau menyajikan data. Hasil reduksi kemudian diorganisasikan dan disusun dalam pola hubungan untuk memudahkan pemahaman dan memudahkan dalam perencanaan kegiatan selanjutnya. Data yang ditampilkan dapat berupa teks naratif, grafik, matriks network dan bagan; c) Verifikasi Data.. Langkah ketiga dari verifikasi data adalah menarik kesimpulan dan memverifikasi. Jika data yang diperoleh pada tahap penyajian adalah data yang lengkap maka dapat ditarik kesimpulan yang kredibel. Namun karena permasalahan dan rumusan masalah dalam penelitian kualitatif masih bersifat sementara, terkadang kesimpulan awal masih kurang kredibel, sehingga peneliti harus kembali ke lokasi untuk mengumpulkan kembali data dan bukti yang efektif. 


\section{Uji Keabsahan Data}

Karena penelitian ini merupakan penelitian kulaitatif, maka proses pengujian data dilakukan dengan pengujian kepercayaan (credibility), keteralihan (transferability), ketergantungan (dependability) dan kepastian (comforability) Komariah \& Satori (2014) a) Uji Kepercayaan (Credibility). Keterpercayaan / kredibilitas merupakan ukuran kebenaran data yang dikumpulkan, yang menggambarkan kecocokan konsep peneliti dengan hasil penelitian. "Kredibilitas data diperiksa melalui kelengkapan data yang diperoleh dari berbagai sumber". Komariah \& Satori (2014) Menurut Sugiyono uji kredibilitas dilakukan dengan beberapa cara: 1) Perpanjang pengamatan yaitu peneliti kembali ke lokasi untuk mengecek kebenaran data yang ditemukan; 2) Meningkatkan ketekunan, yaitu mengamati lebih cermat dan terus menerus untuk memastikan kebenaran suatu data yang ditemukan; 3) Triangulasi; 4) Analisis kasus negatif yaitu untuk mencari kebenaran data yang berbeda, bahkan bertentangan dengan data yang ditemukan; 5) Menggunakan bahan referensi, yaitu menggunakan bahan yang mendukung untuk pembuktian data yang ditemukan oleh para peneliti; 6) Mengadakan member check, untuk mengecek apakah terdapat informasi yang sesuai antara penjelasan penyedia data tentang peneliti dan informasi yang diberikan oleh penyedia data. b) Uji Keteralihan (Transferability). Pengujian transferability adalah validitas eksternal yang menunjukkan keakuratan atau penerapan hasil penelitian kepada orang-orang yang mengambil sampel atau digunakan dalam situasi lain. Oleh karena itu dalam hal ini peneliti dapat memberikan laporan yang rinci, jelas, sistematis dan terpercaya. Ini juga dirancang untuk memungkinkan pembaca memahami dengan jelas hasil penelitian yang dilakukan. c) Uji Ketergantungan (Dependability). Dalam penelitian ini dilakukan uji realiblitas oleh pembimbing dengan cara mengaudit keseluruhan kegiatan peneliti mulai dari cara peneliti mengidentifikasi masalah, masuk ke lapangan, menentukan sumber data, melakukan analisis data, melakukan uji validitas dan membuat kesimpulan. Hal ini untuk mengecek kebenaran data yang dihasilkan oleh peneliti berdasarkan jejak kegiatan lapangannya. d) Uji Kepastian (Comforability). Untuk memastikan keabsahan data dari uji verifiabilitas, peneliti melaporkan setiap rangkaian kegiatan yang dilakukan di lapangan. Pengujian konfirmasi hampir sama dengan pengujian reliabilitas, sehingga dapat dilakukan pengujian pada waktu yang bersamaan. Uji konfirmabilitas mengacu pada pengujian hasil penelitian dan proses yang dilakukan. Jika hasil penelitian merupakan fungsi dari proses penelitian, hal ini menunjukkan bahwa penelitian tersebut telah mencapai standar konfirmabilitas.

\section{Partisipan dan Lokasi Penelitian}

Partisipan dalam penelitian ini adalah pihak sekolah yakni Kepala Sekolah, Wakil Kepala Sekolah bidang kesiswaan, Kepala Unit Pelaksana Teknis (UPT) PPDB, Koordinator Tim Registrasi PPDB SMAMDA, Koordinator IT SMAMDA dan siswa angkatan 2020/2021 SMAMDA. Variasi subjek penelitian ini bertujuan agar memperoleh data informasi dan keterangan secara lengkap. Penentuan sumber data dalam penelitian kualitatif tidak seperti penelitian kuantitaif yang nengunakan data berupa angka dan rumus yang kemudian diolah menjadi sebuah data statistik. Namun Penentuan sumber data dalam penelitian kualitatif dilakukan secara purposive sampling, yakni dipilih berdasarkan pertimbangan dan tujuan tertentu sesuai dengan tujuan yang dianggap representative. Teknik pengambilan data dengan angket terbuka/tertutup sesuai dengan kebutuhan data penelitian. Penentuan lokasi juga merupakan bagian paling penting dalam melakukan sebuah penelitian. Lokasi penelitian berada di SMA Muhammadiyah 2 Sidoarjo yang beralamat di Jl. Mojopahit no.666B Celep, Kecamatan Sidoarjo Kota, Kabupaten Sidoarjo Provinsi Jawa Timur. Alasan pemilihan lokasi ini karena sekolah tersebut merupakan salah satu sekolah rujukan yang melaksanakan program kerja terkait pengelolaan sistem penerimaan peserta didik baru berbasis online dan telah memiliki sistem informasi khusus penerimaan peserta didik baru berupa web sekolah yang sangat menunjang untuk penerapan system penerimaan peseerta didik baru (PPDB) online.

\section{HASIL DAN PEMBAHASAN}

\section{Profil SMA Muhammadiyah 2 Sidoarjo}

SMA Muhammadiyah 2 Sidoarjo merupakan lembaga pendidikan menengah atas yang berdiri pada tahun 1976. Perjalanan panjang selama 40 tahun lebih menyebabkan sekolah ini berpengalaman dalam mengelola pebelajaran yang baik dan berkualitas. Peningkatan mutu pendidikan meningkatkan kepercayaan masyarakat untuk mempercayakan pendidikan di lembaga ini. Saat ini per tahun 2020 SMA Muhammadiyah memiliki jumlah peserta didik sebanyak 1380 dengan 40 rombongan belajar. Perkembangan sumber daya manusia yang sangat banyak ini membutuhkan tenaga pendidik dan kependidikan sebanyak 131 orang guru dan karyawan. Kebutuhan pengelolaan sumber daya manusia yang besar ini dimanfaatkan untuk selalu berusaha mengembangkan dan membaharui berbagai bidang, antara lain sarana dan prasarana, kurikulum, pelaksanaan maupun kultur pembelajaran. Langkah langkah ini bertujuan untuk menmbangun tradisi keilmuan dan spiritualitas keislaman yang nantinya akan menghasilkan pribadi berkualitas yang unggul, beriman dan bertakwa kepada Alllah SWT, menguasai ilmu pengetahuan dan memiliki lifeskill dengan dasar akidah yang luhur. Tujuan sekolah ini tentunya sebagai perwujudan warga sekolah yang memiliki landasan kekuatan dan akhlak yang mulia.

Pembentukan karakter dan pengembangan kompetensi siswa diasah dengan sangat serius untuk keberlanjutan jenjang pendidikan yang lebih tinggi dan kemantaban bersosialisasi di masyarakat. Selain itu warga sekolah dilatih untuk menciptakan komunitas pembelajar dan lembaga sekolah sebagai pusat pengembangan pendidikan Muhammadiyah di Sidoarjo. Manajemen sekolah yang berjalan di lembaga ini berdasarkan pada prinsip prinsip antara lain transparansi, partisipasi, akuntabilitas, sustainable (keberlanjutan), equitas (keseimbangan), dan kejujuran. Semua prinsip ini dilakukan untuk mewujudkan keberlangsungan kepemimpinan pendidikan berparadigma "TORSIE" (Trust, Openness, Realization, Sinergy, Independence, and Empowering).

Visi yang diunggulkan oleh SMA Muhammadiyah 2 Sidoarjo adalah "Islami, Unggul, Sinergi". Dengan misi yang 
dijalankan dalam proses pembelajaran SMA Muhammadiyah 2 Sidoarjo dirumuskan sebagai berikut; a) Membudayakan membaca dan menghafal Al Quran, sholat berjamaah dhuhur/Jumat dan asar, serta berinfak; b) Membiasakan salam, senyum, sapa, berseragam, disiplin, jujur, dan bertanggungjawab; c) Membiasakan sikap peduli terhadap sesama dan lingkungan; d) Meningkatkan profesionalisme tenaga pendidik dan tenaga kependidikan melalui pelatihan, workshop dan seminar; e) Meningkatkan persentase lulusan yang diterima PTN dan PTS unggulan dari $60 \%$ menjadi $65 \%$ melalui Program Intensif Belajar (PIB), Try Out dan kemitraan dengan PTN dan PTS unggulan; f) Meraih juara I tingkat Internasional bidang rekayasa teknologi dan robotika; g) Meraih juara I OSN tingkat provinsi bidang MIPA, Kebumian, Astronomi, Ekonomi, TIK; h) Meraih Juara International Paduan Suara; i) Meraih juara I tingkat provinsi katagori laboran, pustakawan, guru berprestasi melalui pembinaan dan pendampingan kepala sekolah; j) Meraih juara I OSN guru tingkat nasional bidang Kimia, Juara I tingkat provinsi bidang Matematika, Fisika dan Biologi; k) Meraih juara I O2SN tingkat nasional bidang pencak silat dan Karate melalui kegiatan ekstrakurikuler dan kemitraan; 1) Meraih juara I O2SN tingkat provinsi bidang atletik, badminton, futsal dan tenis meja melalui kegiatan ekstrakurikuler dan kemitraan; m) Mengembangkan jejaring (networking) yang dinamis, berskala lokal, regional, nasional, dan internasional) Menjadikan SMAMDA sebagai learning community and development centre (LCDC); o) Mengembangkan sistem informasi manajemen bidang akademik, kesiswaan dan alumni, sarana prasarana, ketenagaan dan keuangan; p) Meningkatkan kepercayaan yang tinggi dari masyarakat, lembaga pendidikan tinggi, dan pemerintah melalui TORSIE (Trust, Openness, Realization, Sinergy, Independence, and Empowering).

\section{Perencanaan PPDB SMA Muhammadiyah 2 Sidoarjo di Era Pandemi Covid-19}

Perencanaan adalah merupakan langkah awal dalam identifikasi untuk mencatat kebutuhan kebutuhan dalam sebuah kegiatan. Dalam perencanaan membutuhkan perincian penyusunan program kegiatan, menyusun langkah langkah dalam proses pelaksanaan sebuah kegiatan. Langkah ini untuk mengidentifikasi kebutuhan mempersiapkan sebuah program maupun kegiatan untuk menghasilkan produk yang bermutu, baik itu produk barang maupun jasa. Juran (1987) menyatakan bahwa dalam mementukan kualitas adalah kesesuaian untuk penggunaan (fitness for use). Produk ini harus sesuai dengan kebutuhan maupun keperluan yang diinginkan oleh pengguna. Dalam proses perencanaan mutu menjadi proses awal dalam suatu siklus manajemen untuk menentukan kualitas mutu. Trilogi Juran menunjukkan adanya tahap awal proses penting yaitu perencanaan

Perencanaan penerimaan peserta didik baru di SMA Muhammadiyah 2 Sidoarjo tahun ajaran 2021/2022 dilakukan pada bulan September atau pada awal tahun ajaran baru. Hal ini berguna untuk merencanakan peserta didik baru yang akan masuk di suatu sekolah. Penerimaan peserta didik baru merupakan salah satu kegiatan pengadaan seleksi calon peserta didik baru. Agenda penerimaan peserta didik baru diawali dengan rapat pimpinan sekolah dan kepala UPT PPDB. Pembahasan Agenda rapat tersebut terdiri dari perumusan kepanitian, menentukan peminatan program studi, menentukan pilihan jalur penerimaan peserta didik baru, membuat persyaratan bagi calon peserta didik baru. Dalam data yang diolah oleh peneliti, dapat dirumuskan bahwa perencanaan PPDB online memiliki karakteristik perencanaan sebagai berikut : a) Melibatkan kepala UPT dan Pimpinan Sekolah; b) Mengadopsi Sistem PPDB dari Sistem tahun sebelumnya, dan; c) Pada saat pertemuan pihak UPT memaparkan perencanaan sistem berdasarkan sistem PPDB tahun sebelumnya, jika disetujui oleh forum rapat maka sistem akan dirumuskan namun apabila ada revisi dan pertimbangan lain maka akan dilakukan penyesuaian terlebih dahulu.

Dalam rumusan perencanaan dibutuhkan beberapa aspek antara lain, penetapan desain kegiatan, kegiatan layanan yang akan diberikan, proses yang dibutuhkan calon wali siswa baru, usaha yang dilakukan oleh personalia, dan kebutuhan operasional untuk menghasilkan sebuah produk jasa yang telah terkualifikasi sebelum akhirnya mengalami proses pendidikan di lembaga pendidikan SMA Muhammadiyah 2 Sidoarjo. Hal ini sesuai dengan prinsip Perencanaan Juran yang menyatakan bahwa penetapan design, layanan, atau proses yang dibutuhkan custosmer, usaha, dan kebutuhan operasional untuk menghasilkan produk sebelum diproduksi. Juran (1987) Pendekatan Juran terhadap perencanaan kualitas (quality planning) melibatkan beberapa aktivitas yakni: I Gusti (2008) 1) Identifikasi pelanggan; 2) Menentukan kebutuhan pelanggan; 3) Menciptakan keistimewaan produk yang dapat memenuhi kebutuhan pelanggan; 4) Menciptakan proses yang mampu menghasilkan keistimewaan produk di bawah kondisi operasi; 5) Mentransfer/mengalihkan proses ke operasi. Dalam proses PPDB online terdapat beberapa aspek yang dapat dirumuskan sebagai berikut.

Identifikasi Pelanggan. Kepala UPT melakukan identifikasi pelanggan dengan melaksanakan evaluasi kegiatan PPDB di tahun sebelumnya. Dalam proses ini hasil evaluasi PPDB tahun sebelumnya mengalami perbaikan perbaikan yang sudah dirumuskan. Apabila ada masukan, saran dan perbaikan akan ditinjau ulang oleh UPT dan Pimpinan Sekolah. Dalam rapat kegiatan tersebut ditentukan identifikasi kebutuhan calon wali siswa baru dan calon siswa baru. Rumusan ini menjadi bahan untuk menentukan kebutuhan pelanggan. Menentukan kebutuhan pelanggan; dalam PPDB Online di tahun sebelumnya banyak sekali kebutuhan pelanggan, yaitu calon wali siswa baru dan calon siswa baru. Kebutuhan pelanggan diantaranya adalah akses informasi, kemudahan pelayanan dalam mendaftarkan putra putrinya. Terutama dalam masa pandemi Covid-19, informasi yang tersedia terbatas. Sehingga dibutuhkan akses informasi yang lengkap, kontinu, mudah diakses, real time, proses yang cepat, transparansi. Kebutuhan kebutuhan ini dapat terlaksana dengan sistem online. Sistem online ini harus dapat mencukupi kebutuhan siswa baru dan calon wali siswa baru. Dengan adanya kecukupan kebutuhan ini maka niscaya kepuasan pelanggan dapat diraih dengan sukses. Menciptakan keistimewaan produk yang dapat memenuhi kebutuhan pelanggan; Dalam PPDB Online 
keleluasaan akses dibutuhkan sebagai permintaan wali siswa baru. Oleh sebab itu PPDB Online ini harus digali agar dapat memiliki kelebihan yang bisa diunggulkan. Kelebihan ini misalnya adalah akses informasi yang lengkap, kontinu, mudah diakses, real time, proses yang cepat, transparansi.

Menciptakan proses yang mampu menghasilkan keistimewaan produk di bawah kondisi operasi; Sebelum adanya Pandemi Covid-19, PPDB Online sudah berjalan. Namun belum seutuhnya online. Belum seutuhnya berjalan dengan baik. Artinya calon wali siswa dan calon siswa baru masih bisa mendaftar secara manual. Calon wali siswa baru dan siswa baru masih harus hadir dalam kegiatan PPDB. Mulai dari Input data pendaftaran (hulu) hingga heregistrasi setelah diterima menjadi siswa baru (hilir). Maka konsep full online ini harus dimatangkan terlebih dahulu kemudian akan menjadi konsep baru dan menjadi operasional kegiatan PPDB Online. Mentransfer/mengalihkan proses ke operasi. Dalam proses PPDB yang akan direncanakan mendatang menggunakan konsep Online secara penuh. Mulai dari Input data pendaftaran (hulu) hingga heregistrasi setelah diterima menjadi siswa baru (hilir) harus menggunakan konsep online. Calon Wali siswa dan siswa baru bisa melaksanakan operasional PPDB dari mana saja dan kapan saja. Sehingga kehadiran Tatap muka bisa diminimalisir. Hal ini terkait imbas adanya Social Distancing yang mengutamaakan kesehatan dan keamanan di masa Pandemi Covid-19.

\section{Pelaksanaan PPDB SMA Muhammadiyah 2 Sidoarjo di Era Pandemi Covid-19}

Pelaksanaan penerimaan peserta didik baru merupakan hasil implementasi dari perencanaan PPDB. Pelaksanaan merupakan proses berlangsungnya kegiatan melalui teknik tertentu agar tercapai tujuan yang diinginkan dari kegiatan tersebut. Penerimaan peserta didik baru merupakan agenda rutin yang di lakukan suatu lembaga pendidikan setiap tahun. Agenda ini dilakukan untuk menjaring calon-calon peserta didik baru yang nantinya akan dididik dan dibina di sekolah. Setiap lembaga pendidikan biasanya memanfaatkan agenda PPDB untuk mencari calon peserta didik yang unggul agar nantinya bisa mengangkat prestasi sekolah dan eksistensi sekolah diantara sekolah terbaik lainnya.

Masa Pandemi Covid-19 membuat panitia pendaftaran peserta didik baru di SMA Muhammadiyah harus menyesuaikan kebijakan pemerintah, Indonesia sebagai salah satu negara terdampak menetapkan beberapa keputusan dalam menghadapi Covid-19 dan itu juga berimbas kepada dunia pendidikan di Indonesia, Beberapa kebijakan Menteri Pendidikan dan Kebudayaan lainnya diantaranya adalah Kementerian Pendidikan Dan Kebudayaan (2020): 1) Pembatalan UN 2020 termasuk uji Kompetensi Keahlian 20202 bagi SMK; 2) Proses Belajar dari Rumah (BDR); 3) Pelaksanaan Ujian Sekolah; 4) Proses Kenaikan Kelas yang tidak mempertimbangkan PAS dalam bentuk tes namun dalam bentuk portofolio dan prestasi yang telah diperoleh sebelumnya atau penugasan, atau tes daring atau asesment jarak jauh lainnya; 5) Mekanisme Penerimaan Peserta Didik Baru (PPDB) sesuai protokol kesehatan. Sistem pendaftaran yang dilakukan SMAMDA secara online, maka ada sebuah mekanisnme pendaftaran yang harus dilalui oleh para calon wali siswa dan calon siswa yang telah ditetapkan oleh pihak
SMAMDA, yaitu sebagai berikut: 1) Calon siswa yang sudah dinyatakan lulus wajib melakukan herregistasi; 2) Calon siswa diberi tagihan pembayaran berupa Dana Pengembangan Pendidikan (DPP) dan Non Dana Pengembangan Pendidikan (Non DPP); 3) Calon siswa melakukan pembayaran melalui transfer sesuai ketentuan yang berlaku; 4) Calon siswa menyerahkan fotocopy Ijazah/Surat Keterangan Lulus, Kartu Keluarga, dan Akta Kelahiran; 5) Calon siswa yang sudah melakukan pembayaran dan melengkapi berkas administrasi berhak untuk mengambil seragam sesuai dengan waktu yang telah ditentukan, dan; 6) Calon siswa yang telah melakukan herregistrasi diberi hak untuk mengundurkan diri sebelum masuk pembelajaran dan biaya yang sudah dikeluarkan tidak bisa ditarik kembali.

Setelah calon peserta didik baru melakukan pembayaran, maka tahapan selanjutnya yang dilakukan adalah pengambilan seragam. Tahapan tersebut dilakukan dengan cara sebagai berikut: 1) Siswa datang ke sekolah sesuai jadwal pengambilan seragam dengan membawa bukti herregistrasi; 2) Petugas seragam memeriksa nomer pendaftaran siswa dan bukti herregistrasi ;3) Siswa memilih ukuran seragam; 4) Petugas melakukan ceklist pengambilan seragam di sistem, dan; 5) Siswa menerima ceklist bukti pengambilan seragam. Evaluasi dalam proses penerimaan peserta didik baru, ada tahapan evaluasi pelaksanaan PPDB dan tindak lanjut dari hasil evaluasi tersebut. Hasil evaluasi sesungguhnya menjadi acuan untuk memnatapkan strategi yang telah dilakukan sebelumnya, atau bahkan juga bisa mengganti strategi karena tidak maksimalnya perencanaan awal yang telah digagas sebelumnya. Evaluasi merupakan tahapan yang digunakan untuk mengetahui tingkat ketercapaian tujuan program dan apabila belum tercapai maka dapat diketahui letak kekurangan yang nantinya dijadikan sebagai bahan koreksi. Hal ini sesuai dengan yang dikemukakan Manullang menjelaskan pengawasan/evaluasi merupakan suatu proses untuk menerapkan pekerjaan apa yang sudah dilaksanakan, menilainya dan bila perlu mengoreksi dengan maksud supaya pelaksanaan sesuai dengan rencana semula. Manullang (2008)

SMAMDA juga melakukan berbagai perubahan strategi dalam proses pelaksanaan PPDB ini. Peneliti melihat bahwa komersialisasi pendidikan bukan menjadi acuan utama dalam proses PPDB tersebut, tetapi lebih melihat kebutuhan kemaslahatan dan keinginan calon wali peserta didik untuk bagaimana bisa mendorong anaknya untuk bersekolah di SMAMDA tanpa harus khawatir akan besarnya biaya yang telah dirumuskan oleh tim PPDB SMAMDA. Jika melihat Konsep Trilogi Juran yang menggambarkan sebuah sistem manajemen mutu yang berkaitan antara perencanaan, pengendalian dan perbaikan atau peningkatan kualitas. Sebagai contoh, SMAMDA telah mampu mengidentifikasi kebutuhan-kebutuhan pelanggan atau calon wali siswa, seperti kondisi ekonomi masyarakat yang tidak stabil di masa pandemi Covid-19. Lalu, menterjemahkan kebutuhan itu ke dalam program kegiatan, yaitu dengan memberikan potongan biaya yang di tahun ajaran sebelumnya tidak terjadi, dan juga kelonggaran dalam pembayaran biaya sekolah. Selanjutnya, menyusun langkah-langkah dalam proses pelaksanaan program untuk menghasilkan produk yang bermutu, yaitu 
dilakukan dengan cara menerapkan potongan biaya untuk calon siswa pada PPDB SMAMDA gelombang 2. Dengan kata lain, konsep Trilogi Juran betul-betul dijalankan oleh SMAMDA karena telah menerapkan terobosan baru dalam pelaksanaan PPDB SMAMDA gelombang 2.

\section{Hasil Capaian PPDB SMA Muhammadiyah 2 Sidoarjo di Era Pandemi Covid-19}

Pelaksanaan penerimaan peserta didik baru di SMA Muhammadiyah 2 Sidoarjo Era pandemi Covid-19 berbasis online ini merupakan implementasi perencanaan PPDB. Setiap kegiatan pelaksanaan merupakan hal pokok yang menunjang keberhasilan tujuan yang akan dicapai setiap kegiatan. Hal ini sesuai dengan pendapat Siagian mengemukakan bahwa pelaksanaan / penggerakan sebagai keseluruhan usaha, cara, teknik dan metode untuk mendorong para anggota panitia agar mau dan ikhlas untuk bekerja dengan sebaik-baiknya demi tercapainya tujuan secara efektif dan efisien. Siagian (2007) Tahap pelaksanaan PPDB online ini berlangsung atas kerjasama antara tim IT dan beberapa panitia yang terkait. Dalam proses pelaksanaan, terdapat aspek pengawasan yang nantinya dilakukan sebagai bahan evaluasi. Proses pengawasan memiliki beberapa jenis kegiatan diantaranya yaitu adanya sistem pelaporan yang terstruktur dengan baik, pengembangan standar perilaku yang disetujui bersama, adanya usaha penentuan hasil dan mutu agar mampu mencapai sebuah tujuan, melakukan koreksi apabila terdapat langkah langkah yang tidak mencapai tujuan, dan pemberian hasil kerja dalam bentuk ganjaran, penghargaan kepada aktivitas yang dapat mencapai tujuan bersama. Hamalik (2006) Dari paparan diatas maka pengawasan sebagai kegiatan yang dilaksanakan secara sistematis dalam usaha untuk mengkoreksi, menilai, membandingkan berbagai usaha dalam pencapaian tujuan sebuah lembaga.

Jika melihat manajemen perencanaan, pelaksanaan, sampai capaian pelaksanaan, maka sesungguhnya SMAMDA telah melakukan prinsip yang telah dikemukakan oleh Juran menggambarkan sebuah sistem manajemen mutu yang berkaitan antara perencanaan, pengendalian dan perbaikan atau peningkatan kualitas. Isi pokok perencanaan mutu ialah mengidentifikasi kebutuhan-kebutuhan pelanggan, menerjemahkan kebutuhan itu ke dalam program kegiatan, dan menyusun langkah-langkah dalam proses pelaksanaan program untuk menghasilkan terobosan kebijakan yang bermutu. Capaian pelaksanaan dalam kegiatan PPDB SMAMDA juga dilakukan dalam bentuk evaluasi oleh pihak penjaminan mutu sekolah melalui penyebaran kuisioner kepada siswa secara online. Evaluasi tersebut bertujuan untuk mengetahui feedback dari siswa terkait pemahaman pengetahuan tentang sekolah, media promosi apa yang paling mudah dijangkau oleh anak di generasi millennial ini, pertimbangan atau alasan dalam memilih sekolah, penilaian terkait sistem PPDB berbasis online, dan penilaian terkait alur PPDB berbasis online. Langkah tersebut dilakukan untuk mengetahui respon dari siswa, sehingga nantinya diharapkan dapat menjadi bahan perbaikan bagi kinerja SMAMDA secara umum dan Tim PPDB SMAMDA secara khusus, sehingga kualitas sistem PPDB SMAMDA berbasis online bisa dinilai secara baik.

\section{KESIMPULAN}

Perencanaan (planning) penerimaan peserta didik baru di SMA Muhammadiyah 2 Sidoarjo dilakukan melalui rapat UPT PPDB dengan pimpinan Sekolah serta tim untuk membahas dan memutuskan apa saja yang harus dilakukan pada saat PPDB di semester genap berjalan. Dalam data yang dimiliki oleh peneliti, dapat dirumuskan bahwa perencanaan PPDB online memiliki karakteristik perencanaan sebagai berikut : a) Melibatkan kepala UPT dan Pimpinan Sekolah; b) Mengadopsi Sistem PPDB dari Sistem tahun sebelumnya, dan; c) Pada saat pertemuan pihak UPT memaparkan perencanaan sistem berdasarkan sistem PPDB tahun sebelumnya, jika disetujui oleh forum rapat maka sistem akan dirumuskan namun apabila ada revisi dan pertimbangan lain maka akan dilakukan penyesuaian terlebih dahulu. Pelaksanaan (actuating) penerimaan peserta didik baru di SMA Muhammadiyah 2 Sidoarjo melalui lima tahapan seleksi yang wajib diikuti oleh calon siswa SMAMDA, yaitu: pertama, Computer Based Test (CBT) bagi pendaftar Bidik Misi, Kerjasama dan Reguler; kedua, Nilai Akademik bagi pendaftar Prestasi Akademik dan Inden; ketiga, Wawancara dan Praktik bagi pendaftar jalur Prestasi Non akademik; keempat, Wawancara bagi pendaftar Bidik Misi, dan; kelima, Tes urine untuk semua jalur pendaftaran. Selanjutnya, pihak UPT PPDB akan mengumumkan hasil ujian di website PPDB SMA Muhammadiyah 2 Sidoarjo melalui akun pendaftar melalui login ppdb. Login PPDB dengan memasukkan no pendaftaran dan password. Capaian pelaksanaan (implementation achievement) penerimaan peserta didik baru di SMA Muhammadiyah 2 Sidoarjo bahwa evaluasi dilakukan untuk nantinya menjadi perbaikan maupun strategi baru dalam proses PPDB SMAMDA. Bahkan, proses evaluasi harus dilakukan di setiap bagian, agar bisa mengetahui kendala atau persoalan apa yang sedang terjadi dalam proses pelaksanaan PPDB dalam masa pergantian gelombang, sehingga nantinya bisa dimunculkan solusi atau jalan keluar melalui forum rapat tim dan pimpinan. Sehingga target siswa dalam proses PPDB SMAMDA bisa tercapai.

\section{UCAPAN TERIMA KASIH}

Kami Ucapan terima kasih kepada segenap civitas akademika SMA Muhammadiyah 2 Sidoarjo karena telah memberikan ijin, kesempatan, informasi dan ruang dalam proses penggalian data. Ucapan terima kasih juga disampaikan kepada Universitas Muhammadiyah Sidoarjo yang telah membimbing dan memberikan kesempatan dan ruang untuk publikasi dalam jurnal Halaqa SINTA 3 sebagai luaran penelitian ini. Selain itu, terima kasih kepada seluruh unsur yang terlibat dalam penelitian ini yang tidak saya sebut satu persatu. Disamping itu, saya ucapkan terimaksih kepada Prof. Dr. Biyanto, M.Ag. selaku Dosen Pembimbing dan Dr. Eni Fariyatul Fahyuni, S.Psi. M.Pd.I selaku Kaprodi dari UMSIDA yang telah membimbing dan mengarahkan kegiatan penelitian, sekaligus mereview penulisan artikel ini sampai dengan publikasi. 


\section{REFERENCES}

Ali, M. (2016) Membedah Tujuan Pendidikan Muhammadiyah. 44PROFETIKA, Jurnal Studi Islam, Vol. 17, No. 1, Juni 2016: 43-56.

Ambarwati, S. (2016) Manajemen Penerimaan Peserta Didik Baru (Ppdb) Online Jenjang Sma Negeri Di Dinas Pendidikan Kota Bandung

Ayu N. A. (2007). Kontribusi Sembilan Dasawarsa dari Muhamadiyyah. https://one1 thousand100education.wordpress.com/2007/07/16/kontribusisembilan-dasawarsa-dari-muhamadiyyah/

Bogdan, R.C \& Biklen, S.K.B..( 1998) Cualitative Research for Education to Theory and Methods. Allyin and Bacon, inc. Boston

Hamalik, O. (2006). Manajemen Pengembangan Kurikulum. Bandung: Remanje Rosdakarya

https://ejournal.bsi.ac.id/ejurnal/index.php/infortech

https://one1 thousand100education.wordpress.com/2007/07/16/kontribusisembilan-dasawarsa-dari-muhamadiyyah/

Juran, J. “The Juran Trilogy”, Quality Progress, Vol. 19, No. 8. Tahun 1986

Kemendikbud and Kementerian Pendidikan dan Kebudayaan, "Surat Edaran Nomor 4 Tahun 2020 Tentang Pelaksanaan Kebijakan Pendidikan Dalam Masa Darurat Penyebaran Coronavirus Disease (COVID 19)" (Jakarta: Kementerian Pendidikan Dan Kebudayaan, 2020)

Kemendikbud, "Surat Edaran Nomor 4 Tahun 2020 Tentang Pelaksanaan Kebijakan Pendidikan Dalam Masa Darurat Penyebaran Corona Virus Disease (Covid-19)" (Jakarta: Kementerian Pendidikan Dan Kebudayaan, 2020).

Komariah, A. Satori., D. (2014) Metodologi Penelitian Kualitatif. Bandung: Alfabeta

Lestari, I. G. Penerapan Sistem Manajemen Mutu ISO 9001:2008 di Perusahaan Konstruksi, Ganeç Swara Vol. 9 no.1. 2015. h.123.

Manullang, M. (2008). Dasar-Dasar Manajemen. Yogyakarta: Gadjah Mada.
Milles, BM \& Huberman, A.M. (1992). Analisis Kualitatif. Penerjemah Rohadi. Jakarta: RT Universitas Indonesia

Pemerintah Kabupaten Sidoarjo, "Geografis," 2020, Available: http://portal.sidoarjokab.go.id/geografis.

Siagian, S. P. (2007). Fungsi-Fungsi Manajerial. Jakarta: PT. Bumi Aksara.

UU RI SISDIKNAS No. 20 Tahun 2003

www.smamda.sch.id/profile

Conflict of Interest Statement: The authors declare that the research was conducted in the absence of any commercial or financial relationships that could be construed as a potential conflict of interest.

Copyright (C) 2021 Muhammad Mauludy Falaakhy, Biyanto, Eni Fariyatul Fahyuni. This is an open-access article distributed under the terms of the Creative Commons Attribution License (CC BY). The use, distribution or reproduction in otherforums is permitted, provided theorigi-nal author(s) and the copyrightowner(s) are credited and that the original publication in this journal is cited, in accordance with accepted academic practice. No use, distri- bution or reproduction is permitted which does not comply with these terms. 